\title{
Ne eat iudex ultra petita partium od prawa rzymskiego do czasów współczesnych. Uwagi na tle polskiego procesu cywilnego
}

\section{Uwagi wprowadzające}

Wliteraturze od wielu lat trwa dyskusja na temat wpływu prawa rzymskiego na prawo współczesne ${ }^{1}$. W dyskusji tej zdecydowanie przeważają argumenty zwolenników poglądu o wpływie prawa rzymskiego na współczesne prawo, w tym w szczególności prawo cywilne materialne i procesowe ${ }^{2}$. Jak to trafnie

\footnotetext{
${ }^{*}$ Dr Agnieszka Laskowska-Hulisz - adiunkt w Katedrze Postępowania Cywilnego Uniwersytetu Mikołaja Kopernika w Toruniu, radca prawny. Autorka publikacji z zakresu postępowania cywilnego, w tym m.in. procesu cywilnego oraz europejskiego prawa procesowego cywilnego; e-mail: agnieszka. laskowska@umk.pl; adres do korespondencji: ul. Św. Józefa 72a/22, 87-100 Toruń.

1 Zob. m.in. H. Kupiszewski, Znaczenie prawa rzymskiego dla współczesności, PiP 1981, z. 8, s. 69 i n.; tenże, Prawo rzymskie a wspótczesność, Warszawa 1988, s. 11 i n.; M. Kuryłowicz, Rzymskie sentencje prawnicze o człowieku, sprawiedliwości i prawie, Palestra 1988, nr 7, s. 71 i n.; W. Wołodkiewicz, Tradycja prawa rzymskiego we współczesnym prawie cywilnym, Palestra 1987, nr 10-11, s. 66 i n.; tenże, Czy prawo rzymskie przestało istnieć?, Palestra 1999, nr 9-10, s. 81 i n. W literaturze za René Davida, analizując wpływ prawa rzymskiego na prawo współczesne, odróżnia się następujące rodziny tego prawa: prawo romańsko-germańskie, Common Law i socjalistyczne. R. Davida odróżniał jeszcze rodzinę prawa opartą na religii i tradycji. Zob. W. Wołodkiewicz, Tradycja..., s. 70-71 oraz powołana tam literatura.

${ }^{2}$ H. Kupiszewski, Znaczenie ..., s. 69 i n.; M. Kuryłowicz, Rzymskie ..., s. 71 i n.; W. Wołodkiewicz, Tradycja ..., s. 66 i n.; tenże, Czy prawo ..., s. 81 i n.; tenże, w: Regulae iuris. Łacińskie inskrypcje na kolumnach Sądu Najwyższego Rzeczypospolitej Polskiej, pod red. W. Wołodkiewicza, Warszawa 2011, s. 5-11; J. Misztal-Konecka, Zakaz wyrokowania ponad żadnie strony(„Ne eat iudex ultra petita partium") - Rzymski tradycje i współczesne regulacje polskiego procesowego prawa cywilnego, Zeszyty Prawnicze 12.4/2012, s. 41-42.
} 
ujął W. Włodkiewicz: „Wartość prawa rzymskiego dla późniejszych dziejów myśli prawniczej i praktyki legislacyjnej polega na tym, że pojęcia i instytucje prawne wykształcone w prawie rzymskim lub na jego podstawie mogły być i są wciąż wykorzystywane - niezależnie od różnych warunków społecznych, gospodarczych i politycznych, którym służą różne systemy prawne. W tym sensie prawo rzymskie stanowi łącznik - co najmniej formalny - między różnymi systemami prawnymi i jest podstawą do lepszego ich zrozumienia"s. Wiele instytucji, które po raz pierwszy zostały opracowane w prawie rzymskim klasycznym jest wykorzystywanych na potrzeby współczesnego procesu cywilnego ${ }^{4}$. Warto przy tym dodać, że pomimo prostoty i skromności prawa rzymskiego w porównaniu do prawa czasów współczesnych, kiedy to „produkowane są całe biblioteki norm prawnych", wiele z instytucji i zasad (sentencji) pochodzących z tego prawa pozostaje do dziś aktualna, zaś dorobek klasyków wykorzystywany na potrzeby wyjaśnienia ich natury na gruncie prawa współczesnego. Jedną z takich sentencji jest wskazana w tytule ne eat iudex ultra petita partium, czyli niech nie wychodzi sędzia ponad żądania stron, która ujmowana jest współcześnie jako zakaz orzekania przez sąd ponad żądanie. W prawie współczesnym sentencja ta jest wyrazem jednej z podstawowych i zarazem najważniejszych zasad orzekania oraz gwarancją realizacji w procesie cywilnym zasady dyspozycyjności. O randze i znaczeniu zasady ne eat iudex ultra petita partium decydują jednak nie tylko jej związki z zasadą dyspozycyjności, a przez nią z zasadą autonomii woli podmiotów prawa prywatnego, ale także istotna funkcja gwarancyjna i ochronna, jaka jest wiązana z zakazem orzekania ponad żądanie ${ }^{6}$. To podmiot, któremu przysługuje dane roszczenie powinien mieć możliwość decydowania o tym, czy będzie go dochodzić przed sądem oraz jakiej treści orzeczenia oczekuje, natomiast sąd w granicach wyznaczonych przez powoda, na podstawie ustalonego stanu faktycznego i obowiązujących przepisów prawa jest uprawniony do orzeczenia o tym roszczeniu. $Z$ uwagi na wagę tej zasady w polskim procesie cywilnym ${ }^{7} \mathrm{w}$ dalszej części publikacji zostanie krótko przybliżona w pierwszej

${ }^{3}$ W. Wołodkiewicz, Tradycja...., s. 84-85.

${ }^{4}$ Bliżej na temat rozwoju prawa rzymskiego oraz jurysprudencji klasycznej: H. Kupiszewski, Znaczenie..., s. 71-74.

${ }^{5}$ Tak, moim zdaniem trafnie ujął to H. Kupiszewski, Znaczenie..., s. 75.

${ }^{6} \mathrm{~K}$. Weitz, Związanie sądu granicami żadania w procesie cywilnym, w: Aurea Praxis Aurea Theoria. Ksiegga pamiątkowa ku czci profesora Tadeusza Erecińskiego, pod red. J. Gudowskiego, K. Weitza, tom I, Warszawa 2011, s. 681-682. Zob. też T. Ereciński, Orzekanie ponad żadanie w sprawach o naprawienie szkody wyrządzonej czynem niedozwolonym (kilka uwag na tle art. 321 $\$ 2$ k.p.c.), w: Odpowiedzialność cywilna. Księga pamiątkowa ku czci Profesora Adama Szpunara, Kraków 2004, s. 114.

7 Zasada ta jest również jedną z 86 paremii, które znalazły się na kolumnach gmachu Sądu Najwyższego w Warszawie przy Placu Krasińskich. Paremia ta została zamieszczona na kolumnie widzianej od wewnątrz z korytarza i sal na I piętrze. Zob. też W. Wołodkiewicz, Czy prawo..., s. 85-86. 
kolejności jej geneza, następnie ewolucja historycznoprawna polskiej regulacji prawnej odnoszącej się do zakazu orzekania ponad żądanie, aby w końcu krótko przedstawić kształt, jaki tej zasadzie nadał ustawodawca polski w kodeksie postępowania cywilnego.

\section{Geneza zasady ne eat iudex ultra petita partium}

Ne eat iudex ultra petita partium nie znajduje dosłownego potwierdzenia w tekstach prawa rzymskiego. Pochodzi ona z późniejszych opracowań nawiązujących do prawa rzymskiego, wskazuje się tu m.in. na sentencję pochodzącą z konstytucji Dioklecjana i Maksymiana (C. 7, 45, 7 pr.) w brzmieniu: Nec vox omnis iudicis iudicati continent auctoritaten, czyli że nie każde słowo sędziego ma powagę wyroku. W swym kontekście zdanie to ma ten sens, że wyrok powinien zawierać merytoryczne rozstrzygnięcie kwestii mieszczących się bezpośrednio w granicach rozpatrywanej sprawy, a nie decydować w kwestiach leżących poza nią. Co oznacza, że i kompetencje sędziego i wydany przez niego wyrok mają swoje granice $^{8}$. W literaturze ${ }^{9}$ wskazuje się także na to, że paremia ta znajduje oparcie we fragmencie lib. 2 epistularum Javolena, przekazanym w 3 tytule 10 księgi Digestów justyniańskich. Chodzi tu o następujący fragment: Ut fundus hereditarius fundo non hereditario serviat, arbiter disponere non potest, quia ultra id guod in iudicium deductum est excedere potestas iudicis non potest (D.10.3.18) ${ }^{10}$. Nicolas Everardi, duński prawnik w początkach XVI wieku, powołując się na dekret Gratiana, formułuje tę zasadę w następujący sposób: Sententia debet esse conformis libello (Loci argumentorum legales 49,1). Paremia ta dotyczyła zakresu uprawnień sądu do rozstrzygania o stosunkach prawnych między stronami. Zgodnie z jej treścią objęte wyrokiem mogą być tylko te sprawy, które zostały ujęte przez stronę w skardze (actio). W procesie formułkowym podlegały one zgłoszeniu w pierwszej fazie procesu przed urzędnikiem w postaci intentio lub

${ }^{8}$ M. Kuryłowicz, Rzymskie..., s. 82; W. Wołodkiewicz, Czy prawo..., s. 82. Bliżej na temat zakazu orzekania ponad żądanie w prawie rzymskim, zob. m.in. K. Amielańczyk, Zasada skargowości i zakaz orzekania ponad żądanie stron w procesie rzymskim, Gdańskie Studia Prawnicze 2015, z. 33, s. 33-46; P. Pogonowski, Znaczenie rzymskich paremii procesowych dla współczesnej procedury cywilnej, [w:] Starożytne kodyfikacje prawa, pod red. A. Dębińskiego, Lublin 2000, s. 187-198.

9 W. Wołodkiewicz, Regulae..., s. 126; J. Misztal-Konecka, Zakaz wyrokowania..., s. 42-44.

${ }^{10}$ Tekst Javolena, do którego nawiązuje paremia dotyczy sytuacji, gdy w toku postępowania o podział majątku spadkowego powstało pytanie, czy jeden ze spadkobierców może uzyskać służebność na gruncie spadkowym dla swojej nieruchomości nienależącej do dzielonego spadku. Jurysta odmówił sędziemu prawa do ustanowienia takiej służebności, ponieważ przedmiotem postępowania jest dział spadku, a poza kwestie związane z jego podziałem sędzia wyjść nie może. Zob. W. Wołodkiewicz, Regulae..., s.126. 
exceptiones formułki procesowej ${ }^{11}$. W postępowaniu kognicyjnym zgłaszane one były w pisemnej skardze (actio) składanej w sądzie. Zgłaszane w ten sposób skargi stawały się przedmiotem postępowania i sędziemu nie wolno było ich zmieniać $\mathrm{w}$ trakcie postępowania. $\mathrm{W}$ procesie formułkowym wynikało to $\mathrm{z}$ faktu, że po zakończeniu pierwszej fazy postępowania następowała konsumpcja skargi. Powstałe w ten sposób wyobrażenie o roli sędziego zostało też przejęte $\mathrm{w}$ procesie kognicyjnym ${ }^{12}$. Podstawą recepcji prawa rzymskiego stało się wykształcone przez komentatorów -począwszy od średniowiecza - rzymskie prawo aktualne. Nastąpiła ona w najpełniejszej formie w Niemczech, gdy Sąd Kameralny Rzeszy w 1495 r. został zobowiązany do orzekania posiłkowo zgodnie z prawem rzymskim (przetworzonym przez glosatorów i komentatorów). Tak zwany usus modernus pandectarum - traktujący prawo rzymskie jako aktualny system prawny - był podejściem do prawa rzymskiego, które trwało jeszcze w XVIII wieku i znalazło swój epilog w XIX-wiecznej pandektystyce. Wiek XIX cechuje zasadniczo odmienne podejście do prawa rzymskiego. $\mathrm{Na}$ gruncie niemieckiej szkoły historycznej wykształca się tzw. pandektystyka, dla której prawo justyniańskie i wyrosła na jego gruncie doktryna były systemem prawa aktualnie obowiązującego. Klasycy szkoły pandektów m.in. C.F. Glück, A. Brinz, H Dernburg, B. Windscheid stworzyli na podstawie źródeł prawa rzymskiego zamknięty system prawny, nadający się do stosowania w warunkach współczesnych. Przykładem tego może być niemiecki kodeks cywilny (BGB) ${ }^{13}$.

\section{Ewolucja historycznoprawna polskiej regulacji prawnej dotyczącej zasady ne eat iudex ultra petita partium}

Zakaz orzekania ponad żądanie uregulowany był w ustawodawstwie państw zaborczych obowiązującym na ziemiach polskich po odzyskaniu niepodległości po pierwszej wojnie światowej (art. 131 i 706 rosyjskiej ustawy postępowania sądowego cywilnego z 1864 r., $\$ 308$ ust. 1 niemieckiej ustawy o procedurze cywilnej z 1877 r. (niemiecko ZPO), $\$ 405$ austriackiej ustawy o postępowaniu sądowym w cywilnych sprawach spornych z 1895 r. (austriackie ZPO) oraz $\$$ 394 ust. 1 węgierskiego kodeksu postępowania cywilnego z 1911 r., obowiązu-

${ }^{11}$ Intentio to część zwyczajna formułki, w której zawarte było roszczenie powoda, natomiast exceptio, to część nadzwyczajna, środek obrony pozwanego, zarzut procesowy. Bliżej zob. m.in. W. Bojarski, Prawo rzymskie, Toruń 1994, s. 64-65.

${ }_{12}$ Zob. W. Wołodkiewicz, Regulae..., s.126-127; W. Wołodkiewicz, M. Zabłocka, Prawo rzymskie. Instytucje, Warszawa 1995, s. 284 i n.

${ }_{13}$ W. Wołodkiewicz, Europa i prawo rzymskie. Szkice z historii europejskiej kultury prawnej, Warszawa 2009, s. 48-50; 369-370. 
jącego do 1922 r. na polskich obszarach Spiszu i Orawy) ${ }^{14}$. Z tych względów nie budziło wątpliwości, że zakaz ten powinien się znaleźć także w polskim kodeksie postępowania cywilnego. Zasadę ne eat iudex ultra petita partium nazwano nawet alfą i omegą postulatu prawodawcy ${ }^{15}$. Zasada ne eat iudex ultra petita partium została więc wprowadzona do kodeksu postępowania cywilnego z 1930 r. $^{16}$ (regulował ją art. 349, po ogłoszeniu w 1932 r. tekstu jednolitego - art. 342, natomiast po ogłoszeniu w 1950 r. tekstu jednolitego - art. 329 d.k.p.c. $\left.{ }^{17}\right)$. Artykuł 349 k.p.c. z 1930 r. brzmiał: "Sąd nie ma prawa wyrokować co do rzeczy, która nie była przedmiotem żądania, ani zasądzać ponad żądanie”.

Na mocy art. 1 pkt 93 ustawy zmieniającej z dnia 20 lipca 1950 r. ${ }^{18}$ dotychczasowy przepis art. 342 stał się $\$ 1$ oraz dodano $\$ 2$ w brzmieniu: „Przepisu paragrafu poprzedzającego nie stosuje się: 1) gdy powodem jest Skarb Państwa lub inny podmiot podlegający państwowemu arbitrażowi gospodarczemu, a wysokość roszczeń nie została określona umową lub przepisami szczególnymi oraz 2) gdy przedmiotem powództwa są roszczenia alimentacyjne ze stosunku pracy lub o naprawienie szkody wyrządzonej czynem niedozwolonym".

Z kolei w tekście pierwotnym obowiązującego kodeksu postępowania cywilnego wprowadzono art. $321 \mathrm{w}$ brzmieniu: „\$ $\$$. Sąd nie może wyrokować co do przedmiotu, który nie był objęty żądaniem, ani zasądzać ponad żądanie. $\$ 2$. Przepisu paragrafu poprzedzającego nie stosuje się, gdy powodem jest jednostka gospodarki uspołecznionej, jak również w sprawach o roszczenia alimentacyjne i o naprawienie szkody wyrządzonej czynem niedozwolonym". $\mathrm{W}$ takich sprawach sąd orzeka o roszczeniach, jakie wynikają z faktów przyto-

${ }^{14}$ Zob. K. Weitz, Zwiazanie...., s. 683-684 oraz powołana tam literatura.

${ }^{15}$ W. Mańkowski, Projekt działu polskiej procedury cywilnej o wyrzeczeniach sądowych, w: Polska procedura cywilna. Projekty referatów z uzasadnieniem. Przedruk wyczerpanych druków z r. 1921 i 1923. Tom I, Warszawa 1928, s. 332-333.

${ }^{16}$ Posługując się określeniem kodeks postępowania cywilnego z 1930 r., mam na myśli kodeks postępowania cywilnego, który został ogłoszony rozporządzeniem Prezydenta RP z dnia 29 listopada 1930 r., z mocą obowiązującą od 1 stycznia 1933 r. (Dz. U. RP z 1930 r. Nr 83, poz. 651). Osobno opracowano tekst prawa egzekucyjnego, który został ogłoszony rozporządzeniem Prezydenta RP z dnia 27 października 1932 r. jako prawo o sądowym postępowaniu egzekucyjnym. Obwieszczeniem Ministra Sprawiedliwości z dnia 1 grudnia 1932 r. ogłoszono jednolity tekst k.p.c., łączący obie części kodeksu (Dz. U. z 1932 r. Nr 112, poz. 934 ze zm.), który wprowadzał też nową numerację przepisów. W tym tekście jednolitym komentowany przepis miał numer 342 . Zob. W. Berutowicz, Postępowanie cywilne w zarysie, Warszawa 1978, s. 33 i n.

${ }_{17}$ Na mocy obwieszczenia Ministra Sprawiedliwości z dnia 25 sierpnia 1950 r. został ogłoszony tekst jednolity kodeksu postępowania cywilnego z 1930 r. (Dz. U. z dnia 30 listopada 1950 r. Nr 43, poz. 394; sprost.: Dz. U. z 1950 r. Nr 53, poz. 489 ze zm.), w którym została wprowadzona nowa numeracja tytułów, działów, rozdziałów, oddziałów, artykułów i paragrafów. Powołując się na przepisy zawarte w ogłoszonym tekście jednolitym kodeksu postępowania cywilnego, będę się posługiwała skrótem d.k.p.c.

18 Ustawa z dnia 20 lipca $1950 \mathrm{r}$. o zmianie przepisów postępowania w sprawach cywilnych, Dz. U. z 1950 r. Nr 38, poz. 349 . Ustawa ta weszła w życie w dniu 1 października 1950 r. 
czonych przez powoda także wówczas, gdy roszczenie nie było objęte żądaniem lub gdy było w nim zgłoszone w rozmiarze mniejszym niż usprawiedliwiony wynikiem postępowania. Na mocy art. 1 pkt 24 ustawy zmieniającej z dnia 13 lipca $1990 \mathrm{r}^{19}{ }^{19}$ zmieniono treść $\$ 2$. zd. 1. poprzez ograniczenie spraw, w których sąd może orzekać ponad żądanie powoda, do spraw o roszczenia alimentacyjne i o naprawienie szkody. $Z$ kolei na mocy art. 1 pkt 36 ustawy zmieniającej z dnia 2 lipca 2004 r. ${ }^{20}$ uchylono $\$ 2$ art. 321 k.p.c.

Ponadto na mocy art. 1 pkt 19 ustawy zmieniającej z dnia 18 kwietnia 1985 r. $^{21}$ w sprawach ze stosunku pracy został dodany art. $477^{1}$ k.p.c., według którego: „ $\$$. Sąd wydając wyrok orzeka o roszczeniach, które wynikają $\mathrm{z}$ faktów przytoczonych przez pracownika także wówczas, gdy roszczenie nie było objęte żądaniem pracownika lub gdy było zgłoszone w rozmiarze mniejszym niż usprawiedliwiony wynikiem postępowania. Przepisy o uzupełnieniu wyroku stosuje się odpowiednio. $\$ 2$. Jeżeli pracownik dokonał wyboru jednego z przysługujących mu alternatywnie roszczeń, a zgłoszone roszczenie okaże się nieuzasadnione, sąd może także $\mathrm{z}$ urzędu uwzględnić inne roszczenie alternatywne". Na podstawie art. 29 pkt 6 ustawy zmieniającej z dnia 2 lutego 1996 r. ${ }^{22}$ dodano w art. $477^{1}$ k.p.c. $\$ 1^{1} \mathrm{w}$ brzmieniu: „Sąd wydając wyrok w sprawie o ustalenie istnienia stosunku pracy nie może oddalić powództwa tylko na tej podstawie, że powód nie udowodnił wszystkich faktów niezbędnych do takiego ustalenia, $w$ takim wypadku sąd prowadzi postępowanie dowodowe $\mathrm{z}$ urzędu". Następnie na mocy art. 1 pkt 66 ustawy z dnia 2 lipca $2004 \mathrm{r}^{23}$ art. $477^{1}$ k.p.c. otrzymał brzmienie: „Jeżeli pracownik dokonał wyboru jednego z przysługujących mu alternatywnie roszczeń, a zgłoszone roszczenie okaże się nieuzasadnione, sąd może także $z$ urzędu uwzględnić inne roszczenie alternatywne". Z zestawienia zmian art. $477^{1}$ k.p.c. wynika, że od zmiany przepisów kodeksu postępowania cywilnego z dnia 2 lipca 2004 r., która weszła w życie $\mathrm{w}$ dniu 5 lutego $2005 \mathrm{r}$. nastąpił powrót do zasady obowiązującej w tym zakresie przed 1 października 1950 r., według której sąd nie może wyrokować co do przedmiotu, który nie był objęty żądaniem, ani zasądzać ponad żądanie. W literaturze zmiany te były postrzegane jako służące efektywności ochrony

19 Ustawa z dnia 13 lipca 1990 r. o zmianie ustawy - Kodeks postępowania cywilnego, Dz. U. 1990 r. Nr 55, poz. 318. Ustawa weszła w życie w dniu 1 października $1990 \mathrm{r}$.

${ }^{20}$ Ustawa z dnia 2 lipca 2004 r. o zmianie ustawy - Kodeks postępowania cywilnego oraz niektórych innych ustaw, Dz. U. 2004 r. Nr 172, poz. 1804. Ustawa ta weszła w życie w dniu 5 lutego 2005 r.

${ }^{21}$ Ustawa z dnia 18 kwietnia 1985 r. o zmianie ustawy - Kodeks postępowania cywilnego, Dz. U. 1985 r. Nr 20, poz. 86.

${ }^{22}$ Ustawa z dnia 2 lutego 1996 r. o zmianie ustawy - Kodeks pracy oraz o zmianie niektórych ustaw, Dz. U. 1996 r. Nr 24, poz. 110.

${ }^{23}$ Ustawa z dnia 2 lipca 2004 r. o zmianie ustawy - Kodeks postępowania cywilnego oraz niektórych innych ustaw, Dz. U. 2004 r. Nr 172, poz. 1804. Ustawa ta weszła w życie w dniu 5 lutego 2005 r. 
prawnej ${ }^{24}$. Wskazywano jednocześnie na to, że jedynie związanie sądu granicami żądania odpowiada modelowi procesu, w którym obowiązują zasady dyspozycyjności i kontradyktoryjności, zaś przepisy, tj. art. $321 \S 2$ oraz $477^{1} \S 1$ i $\$ 1^{1}$ k.p.c. pozostawały w rażącej sprzeczności z zasadą wolności i autonomii praw prywatnych ${ }^{25}$.

\section{Ne eat iudex ultra petita partium w kodeksie postępowania cywilnego}

Artykuł $321 \$ 1$ k.p.c., stosownie do którego sąd nie może wyrokować co do przedmiotu, który nie był objęty żądaniem, ani zasądzać ponad żądanie, z jednej strony jest wyrazem panującej w procesie cywilnym zasady dyspozycyjności, z drugiej zaś wpływa znacząco na określenie zakresu orzekania sądu pierwszej instancji w procesie cywilnym. W literaturze wskazuje się, że oznaczenie tego zakresu należy wiązać nie tylko z treścią art. $321 \$ 1$ k.p.c., ale także z tymi przepisami prawa, które nakładają na sąd obowiązek orzekania ex lege o określonych materiach poza głównym przedmiotem sporu ${ }^{26}$.

Wyznaczona przez ustawodawcę $\mathrm{w}$ art. $321 \$ 1$ k.p.c. zasada dotyczy przedmiotu orzekania sądu pierwszej instancji w procesie cywilnym w postępowaniu zwykłym oraz postępowaniach odrębnych ${ }^{27}$. Ma ona zasadniczo zastosowanie do wszystkich rodzajów powództw oraz roszczeń (nie tylko głównych, ale i ubocznych). Na podstawie art. $13 \$ 2$ k.p.c. zasada ta ma również odpowiednie zastosowanie $\mathrm{w}$ postępowaniu nieprocesowym, chyba że przepisy o tym postępowaniu będą stanowiły inaczej.

Bliższa analiza tej zasady wymaga zatem poczynienia stosownych rozważań na temat przedmiotu procesu cywilnego (przedmiotu sporu) i jego stosunku do przedmiotu orzekania sądu I instancji ${ }^{28}$. W literaturze operuje się m.in. zwrotami

${ }^{24}$ T. Ereciński, K. Weitz, Efektywność ochrony prawnej udzielanej przez sądy w Polsce, PS 2005, nr 10, s. 16-17.

${ }_{25}$ T. Ereciński, Orzekanie ponad żądanie w sprawach o naprawienie szkody wyrządzonej czynem niedozwolonym (kilka uwag na tle art. $321 \$ 2$ k.p.c., w: Odpowiedzialnośćcywilna. Księga Pamiątkowa ku czci Profesora Adama Szpunara, Kraków 2004, s. 124; T. Ereciński, K. Weitz, Efektywność..., s. 24; P. Pogonowski, Realizacja prawa do sądu w postępowaniu cywilnym, Warszawa 2005, s. 109, przypis 212.

${ }^{26}$ Zob. K. Piasecki, Zasady orzekania, w: System prawa procesowego cywilnego. Postępowanie rozpoznawcze przed sądami pierwszej instancji. Tom II, pod red. Z. Resicha, red. naczelny W. Berutowicz, Wrocław-Warszawa-Kraków-Gdańsk-Łódź 1987, s. 272. Autor ten na gruncie poprzedniego stanu prawnego wskazywał, że na zakres ten wpływa także możliwość orzekania przez sąd ponad żądanie.

${ }_{27}$ Podziału zasad orzekania dotyczących przedmiotu orzekania dokonał W. Siedlecki, Zasady wyrokowania w procesie cywilnym, Warszawa 1957, s. 142 i n.; tenże, Zasady orzekania w postępowaniu cywilnym, NP 1965, nr 6, s. 591.

${ }^{28}$ W literaturze nie ma jednak zgodności poglądów co do tego, czy zagadnienie związania sądu granicami żądania należy łączyć z problematyką przedmiotu sporu (procesu), czy też ustalenie zakresu związania sądu granicami żądania możliwe jest przez odwołanie się do żądania i jego uzasadnienia. Bliżej K. Weitz, Związanie..., s. 688-695. 
„przedmiot procesu”, „przedmiot powództwa”, „przedmiot rozstrzygnięcia”, "przedmiot sprawy”, „przedmiot wyroku”, „przedmiot orzekania”29. Brak jest jednak jednomyślności co do stosunku tych zwrotów do siebie. ${ }^{30}$. Pomijając szczegółowe rozważania na ten temat, na potrzeby niniejszego artykułu, należy podzielić pogląd, że przedmiot procesu ściśle wiąże się z przedmiotem wyroku, ponieważ wyrok zawiera rozstrzygnięcie o przedmiocie procesu ${ }^{31}$. Między koncepcją przedmiotu procesu cywilnego i przedmiotu wyroku zachodzi stosunek odwzorcowania. W zależności od przyjętej koncepcji przedmiotu procesu cywilnego różnie określa się przedmiot orzekania, wskazuje się bowiem, że przedmiotem wyroku jest bądź roszczenie procesowe, bądź np. sytuacja prawna ${ }^{32}$. Z kolei posługiwanie się zwrotem „przedmiot orzekania” jest w pełni aktualne na gruncie postępowania nieprocesowego, w którym sąd rozstrzyga merytorycznie sprawę postanowieniem ${ }^{33}$, a także wtedy, gdy sąd wydaje orzeczenie kończące postępowanie w sprawie, ale nie rozstrzyga nim sprawy co do istoty, np. umarza postępowanie lub odrzuca pozew. Przedmiot procesu powinien być przedmiotem orzekania sądu, nie zawsze jednak sąd będzie zobowiązany do rozstrzygnięcia w wyroku o całym przedmiocie procesu, np. jeżeli powód częściowo cofnie pozew. W takim wypadku sąd będzie orzekał o całym przedmiocie procesu, ale wyrokował jedynie o jego części, tej którą powód pozostawił sądowi do merytorycznego rozstrzygnięcia.

Zasada ne eat iudex ultra petita partium wskazuje zatem, że uprawnienie do wszczęcia procesu cywilnego oraz do wyznaczenia granic poszukiwanej przed sądem ochrony prawnej przysługuje uprawnionemu podmiotowi. Co z kolei wyraża się w tym, że sąd nie może wszcząć procesu bez wniosku (pozwu) strony, nie może orzekać co do przedmiotu, który nie był objęty żądaniem ani zasądzać ponad żądanie. Sąd w zakresie wszczęcia procesu, określenia jego przedmiotu, dokonywania w nim zmian, jego badania, a w konsekwencji rozpoznawania i rozstrzygania sprawy jest związany wnioskami stron. To strony zatem, w granicach określonych przez prawo, wyznaczają sądowi zakres orzekania. Zakres ten wyjątkowo i tylko częściowo może być modyfikowany przez sąd, ale tylko w wypadkach wskazanych w ustawie.

${ }^{29} \mathrm{~W}$ kodeksie postępowania cywilnego ustawodawca posługuje się z kolei następującymi zwrotami: przedmiot sporu (np. w art. 17 pkt 4, $19 \$ 1,72 \$ 1$ k.p.c.), przedmiot sprawy (np. art. 87 $\$ 1,150$ pkt 3 k.p.c., ), przedmiot rozstrzygnięcia (art. 366 k.p.c.). Słowo „przedmiot” używane jest także w odniesieniu do np. dowodu (np. art. 227 k.p.c.), zaskarżenia (np. art. $378 \$ 2$ k.p.c.).

${ }^{30}$ Zob. bliżej K. Piasecki, Wyrok pierwszej instancji w procesie cywilnym, Warszawa 1981, s. 73-75.

${ }_{31}$ Zob. K. Piasecki, Wyrok pierwszej..., s. 50 i 75; W. Broniewicz, recenzja pracy K. Piaseckiego, Wyrok pierwszej instancji w procesie cywilnym, Warszawa 1981, Pal. 1982, nr 6-7, s. 87-88. Por. też K. Korzan, Orzeczenia konstytutywne w postępowaniu cywilnym, Warszawa 1972, s. 144.

${ }^{32}$ Bliżej K. Piasecki, Wyrok pierwszej..., s. 73-75 oraz powołana tam literatura.

${ }^{33}$ Zob. bliżej K. Markiewicz, Zasady orzekania..., s. 125 i n. 
Orzekanie bez żądania strony, ponad jej żądanie lub o innym żądaniu niż zgłoszone możliwe jest tylko wtedy, gdy ustawa wyraźnie tak stanowi. Wyjątki od zakazu ne eat iudex ultra petita partium zostały wprowadzone nie tylko do kodeksu postępowania cywilnego, ale także do innych ustaw, dotyczą one orzekania przez sąd nie tylko o kwestiach materialnoprawnych, ale także procesowych. Wyjątki te można podzielić na dwie grupy, do pierwszej należy zaliczyć wypadki orzekania bez żądania, np. w postępowaniu w sprawach małżeńskich o rozwód albo separację sąd z urzędu orzeka o winie w rozkładzie pożycia małżeńskiego, władzy rodzicielskiej nad wspólnymi małoletnimi dziećmi stron i kontaktach z dzieckiem oraz obowiązku alimentacyjnym wobec dziecka, a także o sposobie korzystania z mieszkania przez czas wspólnego zamieszkiwania w nim przez rozwiedzionych małżonków (art. 58 k.r.o., 58 w zw. z art. $61^{3}$ k.r.o.); w postępowanie o wydanie lokalu mieszkalnego (tzw. eksmisję, art. 14 ustawy z dnia 21 czerwca 2001 r. o ochronie praw lokatorów, mieszkaniowym zasobie gminy i o zmianie Kodeksu cywilnego ${ }^{34}$ ) sąd $\mathrm{z}$ urzędu orzeka o uprawnieniu do otrzymania lokalu socjalnego bądź o braku takiego uprawnienia wobec osób, których nakaz opuszczenia lokalu dotyczy; o kosztach procesu należnych stronie działającej bez adwokata, radcy prawnego i rzecznika patentowego (art. $109 \$$ 1 zd. 2 k.p.c.); o rygorze natychmiastowej wykonalności, np. gdy wydaje wyrok z uznania lub wyrok zaoczny uwzględniający powództwo (art. $333 \$ 1$ i $2,477^{2} \S$ 1 k.p.c.); o nadaniu klauzuli wykonalności (art. $477^{6} \$ 3,782$ k.p.c.). Natomiast do drugiej grupy można zaliczyć te wypadki, w których sąd uwzględniając powództwo, orzeka o innym roszczeniu niż zgłoszone przez powoda, o ile wynika ono z przytoczonych przez strony okoliczności faktycznych. Chodzi tu o orzekanie w postępowaniu w sprawach z zakresu prawa pracy i ubezpieczeń społecznych o roszczeniu zgłoszonym przez pracownika, jeżeli pracownik dokonał wyboru jednego z przysługujących mu alternatywnie roszczeń, a zgłoszone roszczenie okaże się nieuzasadnione (art. $477^{1}$ k.p.c.) oraz orzekanie o roszczeniach opartych na art. $357^{1}$ oraz $358^{1} \$ 3$ k.c., tj. odpowiednio w wypadku jeżeli z powodu nadzwyczajnej zmiany stosunków spełnienie świadczenia byłoby połączone $\mathrm{z}$ nadmiernymi trudnościami albo groziłoby jednej ze stron rażącą stratą, czego strony nie przewidywały przy zawarciu umowy, sąd może po rozważeniu interesów stron, zgodnie z zasadami współżycia społecznego, oznaczyć sposób wykonania zobowiązania, wysokość świadczenia lub nawet orzec o rozwiązaniu umowy. Rozwiązując umowę, sąd może w miarę potrzeby orzec o rozliczeniach stron, kierując się zasadami określonymi w zdaniu poprzedzającym (art. 357 k.c.), a także w razie istotnej zmiany siły nabywczej pieniądza po powstaniu zobowiązania, sąd może po rozważeniu interesów stron, zgodnie z zasadami

${ }^{34}$ Tekst jednolity: Dz. U. z 2016 r., poz. 1610 ze zm., zwana dalej ustawą o ochronie praw lokatorów. 
współżycia społecznego, zmienić wysokość lub sposób spełnienia świadczenia pieniężnego, chociażby były ustalone w orzeczeniu lub umowie (art. $358^{1} \S 3$ k.c.) ${ }^{35}$.

Jednocześnie warto również podkreślić, że na mocy przepisów szczególnych, zakres orzekania sądu może być ograniczony, co w konsekwencji będzie prowadzić do tego, że przedmiotem badania i orzekania sądu może być tylko wycinek żądania zgłoszonego przez stronę, o ile sformułowała ona swoje żądanie szerzej lub powołała na jego uzasadnienie okoliczności inne niż pozwala na to ustawa. $\mathrm{Z}$ taką sytuacją będziemy mieć do czynienia w postępowaniu w sprawach o naruszenie posiadania, w którym stosownie do treści art. 478 k.p.c. sąd będzie uprawniony zbadać jedynie ostatni stan posiadania i fakt jego naruszenia, nie rozpoznając samego prawa ani dobrej wiary pozwanego ${ }^{36}$.

Jeżeli jednak brak jest przepisu, który ograniczałby zakres orzekania sądu lub uprawniał sąd do orzekania bez żądania lub o innym żądaniu niż zgłoszone przez powoda, sąd zobowiązany jest do orzekania w granicach wyznaczonych mu przez żądanie powoda. Co oznacza, że sąd nie może orzec o czymś więcej niż powód żąda (plus, maius lub super, ograniczenie ilościowe) lub o czymś innym niż żąda strona (aliud, ograniczenie jakościowe). W obu wypadkach chodzi o zakaz, który działa „dwukierunkowo”, a więc zarówno wtedy, gdy sąd uwzględnia, jak i gdy oddala powództwo. Należy przy tym dodać, że sąd może oddalić powództwo, gdy w jego ocenie jest ono bezzasadne także wtedy, gdy pozwany nie wnosi o oddalenie. Zasada związania sądu żądaniem pozwu dotyczy tylko powoda. Ograniczenie ilościowe polega zatem na tym, że sąd nie może zasądzić więcej niż powód żąda nawet wtedy, gdy wynika to z okoliczności faktycznych przytoczonych przez powoda (np. nie może zasądzić wyższej kwoty). Z kolei ograniczenie jakościowe polega na tym, że sąd nie może orzekać o innych żądaniach niż zgłoszone przez powoda (np. nie może zasądzić świadczenia, gdy powód żąda tylko ustalenia istnienia stosunku prawnego, z którego obowiązek świadczenia wynika). Sąd w celu uwzględnienia powództwa nie

${ }^{35}$ Tak też K. Weitz, Związanie..., s. 713. W wyroku z dnia 13 marca 2002 r. SN postawił tezę: Przepis art. 357[1] KC należy do tzw. prawa sędziowskiego i stanowi lex specialis w stosunku do art. $321 \mathrm{KPC}$. W sprawie dotyczącej zastosowania klauzuli rebus sic stantibus sąd nie jest związany żądaniem pozwu (III CKN 568/99, niepubl. Podobnie SN w wyroku z dnia 14 stycznia 2009 r., IV CSK 385/08, niepubl.

${ }^{36}$ Bliżej m.in. J. Krajewski, Odrębności postępowania posesoryjnego, NP 1961, nr 2, s. 214; A. Kunicki, Wyrokowanie w sprawach posesoryjnych, NP 1962, nr 12, s. 1600 i n.; P. Osowy, P. Pełczyński, Sądowa ochrona posiadania - zagadnienia spójności uregulowań kodeksu cywilnego i kodeksu postępowania cywilnego, PS 2001, nr 6, s. 15 i n.; P. Osowy, Roszczenie posesoryjne na przykładzie powództwa o wstrzymanie budowy - spójność uregulowań k.c. i k.p.c. (zagadnienia proceduralne), Rejent 2002, nr 4, s. 87 i n.; M. Manowska, Postępowania odrębne w procesie cywilnym, Warszawa 2010, s. 121 i n.; D. Ruta, Merytoryczna obrona pozwanego w postępowaniu w sprawach o naruszenie posiadania, Pal. 2012, nr 5-6, s. 66 i n. Początków ochrony posiadania należy jednak doszukiwać się w prawie rzymskim. Bliżej m.in. A. Stelmachowski, Istota i funkcja posiadania, Warszawa 1958, s. 255 i n.; J. Ignatowicz, Ochrona posiadania, Warszawa 1963, s. 113 i n. 
może też samodzielnie zmienić żądania powoda, nawet wtedy gdy wynika ono z okoliczności faktycznych przytoczonych przez powoda, ale nie zostało przez niego sformułowane, np. nie może zasądzić odszkodowania w miejsce zniszczonej przez pozwanego rzeczy, której wydania w toku procesu żąda powód.

$\mathrm{Z}$ zakazu ne eat iudex ultra petita partium wyprowadza się również wniosek, że sąd nie może orzekać bez żądania stron ${ }^{37}$. Co oznacza, że sąd nie może wszcząć procesu cywilnego bez żądania strony, czyli z urzędu; nie może orzekać o żądaniu, z którego dochodzenia przed sądem powód zrezygnował, cofając pozew; a także o innych roszczeniach niż tylko te zgłoszone przez powoda nawet, jeżeli wynikają one z przytoczonych przez powoda okoliczności faktycznych. Orzekanie przez sąd w wymienionych wypadkach stanowiłoby naruszenie przede wszystkim zasady nemo iudex sine actore lub ne procedat iudex ex officio ${ }^{38}$.

$\mathrm{Na}$ tle zakazu orzekania ponad żądanie w literaturze spornych jest kilka kwestii, których omówienie $\mathrm{w}$ ramach niniejszego artykułu, $\mathrm{z}$ uwagi na ograniczone ramy wydawnicze jest niemożliwe, $\mathrm{z}$ tych względów ograniczę się do przybliżenia kilku z nich. W pierwszej kolejności warto zastanowić się nad tym, jak należy ocenić sytuację, w której sąd orzeka na innej podstawie faktycznej niż przytoczona przez powoda. Kontrowersyjna jest również kwestia zmiany podstawy prawnej żądania powoda, a także kwestia dopuszczalności doprecyzowania przez sąd żądania powoda.

Jeżeli chodzi o pierwsze zagadnienie, tj. orzekanie przez sąd na innej podstawie faktycznej niż przytoczona przez powoda, to można tu wyróżnić zasadniczo dwa stanowiska. Według pierwszego poglądu wypadek, gdy sąd orzeka na innej podstawie faktycznej niż przytoczona przez powoda, niezależnie od tego, czy orzeka zgodnie z żądaniem, czy też w sposób odmienny stanowi trzecią postać zakazu ne eat iudex ultra petita partium ${ }^{39}$. Z kolei według drugiego poglądu orzekanie na innej podstawie faktycznej niż przytoczona przez powoda, niezależnie od tego, czy sąd orzeka zgodnie z żądaniem, czy też w sposób odmienny nie stanowi trzeciej postaci zakazu ne eat iudex ultra petita partium, lecz jest to orzekanie o czymś co nie było objęte przedmiotem żądania (aliud). Skoro bowiem żądanie indywidualizuje jego treść i podstawa faktyczna, to nie tylko

37 K. Weitz, Związanie..., s. 698 i n.

${ }^{38}$ K. Weitz, Związanie..., s. 702-703.

39 W. Siedlecki, Zasady wyrokowania w procesie cywilnym, Warszawa 1957, s. 44; J. Jodłowski, Z zagadnień polskiego procesu cywilnego, Warszawa 1961, s. 102; K. Piasecki, Orzekanie ponad żadanie w procesie cywilnym, Warszawa 1975, s. 11; tenże, Zasady orzekania, w: System prawa procesowego cywilnego. Postępowanie rozpoznawcze przed sadami pierwszej instancji, tom II, pod red. Z. Resicha, Wrocław-Warszawa-Kraków-Gdańsk-Łódź 1987, s. 272; A. Struzik, Da mihi factum dabo tibi ius, w: Aurea Praxis Aurea Theoria. Księga pamiątkowa ku czci profesora Tadeusza Erecińskiego, pod red. J. Gudowskiego, K. Weitza, tom I, Warszawa 2011, s. 600; J. Misztal-Konecka, Zakaz wyrokowania..., s. 45. 
rozstrzygnięcie o innej treści niż żądana, ale także rozstrzygnięcie na innej podstawie faktycznej niż wskazana przez powoda, choćby o treści zgodnej z żądaną również stanowi orzeczenie o innym roszczeniu niż określone przez powoda $^{40}$. Dodatkowo należy zauważyć, że z treści art. $321 \S 1$ k.p.c. wynika nie tylko zasada związania sądu żądaniem pozwu, ale także zakaz orzekania o przedmiocie, który nie był objęty żądaniem. Z art. $321 \S 1$ k.p.c. wynika zatem zasada związania sądu żądaniem pozwu, która nie rozciąga się na okoliczności faktyczne, stanowiące odrębny od żądania element powództwa, nie oznacza to jednak, że sąd ma dowolność w zakresie badania okoliczności faktycznych. Z powołanego przepisu wynika bowiem zakaz orzekania o przedmiocie, który nie był objęty żądaniem. Natomiast przedmiot orzekania określa nie tylko żądanie, ale także okoliczności faktyczne powołane na jego uzasadnienie. Jeżeli zatem sąd orzeka na podstawie okoliczności faktycznych niepowołanych przez strony, nawet gdy odnosi się do żądania powoda, to orzeka on o przedmiocie, który nie był objęty żądaniem.

Kilka uwag należy również poczynić na tle zmiany przez sąd podstawy prawnej powołanej przez powoda. Powód nie jest zobowiązany do wskazania w pozwie lub innym piśmie procesowym podstawy prawnej dochodzonych przed sądem żądań, natomiast sąd, o ile powód taką podstawę poda, nie jest nią związany. Sporne jest, czy sąd dopuszcza się naruszenia art. $321 \$ 1$ k.p.c., gdy orzeknie na innej podstawie prawnej niż wskazana przez powoda. Wiele uwagi poświęcono wypadkom, w których powód dochodził roszczenia z umowy, sąd zaś przyjął, że umowa jest nieważna i zasądził na rzecz powoda dochodzone roszczenie, ale powołując się na przepisy o bezpodstawnym wzbogaceniu. Według jednego poglądu zmianę taką należy jednocześnie traktować jako zmianę okoliczności faktycznych, ponieważ sąd w istocie zmienia podstawę faktyczną powództwa ${ }^{41}$. Z kolei według drugiego, zmiana we wskazanym wypadku przez sąd podstawy prawnej powództwa nie prowadzi do zmiany podstawy faktycznej powództwa, lecz jest konsekwencją odmiennej oceny prawnej. Sprzeczność zawartej umowy z przepisami prawa nie rodzi żadnego nowego faktu, wykraczającego poza podstawę faktyczną żądania ani nie zmienia samego żądania, którego przedmiotem był i jest zwrot kwoty wręczonej pozwanemu ${ }^{42}$. Problem powstaje także $w$ tych wypadkach, w których powód tak konstruuje podstawę faktyczną żądania, że może być ona kwalifikowana według różnych podstaw prawnych. Jeżeli powód żadnej z tych podstaw nie powołuje, sąd powinien z urzędu rozważyć każdą

${ }^{40}$ K. Weitz, Związanie..., s. 702.

${ }^{41}$ Tak m.in. W. Siedlecki, Zasady orzekania w postępowaniu cywilnym, NP 1965, nr 6, s. 589; P. Telenga, w: Kodeks postępowania cywilnego. Tom I. Art. 1-729, pod red. A. Jakubeckiego, Warszawa 2017, s. 532.

${ }^{42}$ E. Łętowska, glosa do wyroku SN z 18 marca 2005 r., II CK 556/04, PiP 2005, z. 10, s. 123; A. Struzik, Da mihi, w : Aurea..., s. 605. Podobnie J. Misztal-Konecka, Zakaz wyrokowania..., s. 51. 
z tych podstaw przy rozstrzyganiu sprawy. Jeżeli zaś powód powołuje się przy tak skonstruowanym stanie faktycznym na jedną z podstaw prawnych, to dyskusyjne jest, czy sąd powinien rozważyć zastosowanie tylko tej powołanej przez powoda podstawy prawnej, czy też powinien przeanalizować stan faktyczny w świetle wszystkich przepisów prawa ${ }^{43}$. Rozważania te warto uzupełnić o stanowisko Sądu Najwyższego. Otóż Sąd Najwyższy wielokrotnie wypowiadał się co do wagi i znaczenia zasad da mihi factum dabo tibi ius oraz iura novit curia. W wyroku z dnia 2 maja $1957 \mathrm{r}^{44}$ Sąd Najwyższy stwierdził, jeszcze na tle poprzednich przepisów kodeksu postępowania cywilnego, że sądowi nie wolno zasądzać czegokolwiek na podstawie innego stanu faktycznego, niż ten, który jest podstawą powództwa, ale też chodzi o podstawę faktyczną a nie dokonaną kwalifikację prawną. Podobne stanowisko prezentuje Sąd Najwyższy na gruncie obecnych przepisów kodeksu postępowania cywilnego, w wyroku z dnia 23 lutego 1999 $\mathrm{r}^{45}$ oraz w wyroku z dnia 12 lutego $2002 \mathrm{r}^{46}$, stwierdził, że powód ma jedynie obowiązek przytoczenia okoliczności faktycznych uzasadniających żądanie, a konstrukcja prawna rozstrzygnięcia należy do sądu, który nie jest związany podstawą prawną powództwa i może badać jej prawidłowość. Jeszcze dobitniej jest ta myśl wyrażona w wyroku SN z dnia 6 grudnia 2006 r. $^{47}$, według którego „jeżeli z powołanych w pozwie okoliczności faktycznych wynika, że roszczenie jest uzasadnione w całości bądź w części, to należy go w takim zakresie uwzględnić, chociażby powód nie wskazał podstawy prawnej albo przytoczona przez niego okazała się błędna". Podobne zdanie jest wyrażone w wyroku z dnia 27 marca $2008 \mathrm{r}^{48}$ oraz w wyroku SN z dnia 9 maja $2008 \mathrm{r}^{49}$, w którym stwierdza się, że chociaż w razie wręcz niewłaściwego sformułowania żądania sąd może je odpowiednio zmodyfikować, ale tylko zgodnie $z$ wolą powoda, a ponadto „Związanie sądu granicami żądania obejmuje nie tylko związanie co do samej treści (wysokości) żądania zasadniczego, ale także co do uzasadniających je elementów motywacyjnych”. Podobnie w wyroku z dnia 16 września 2009 r. Sąd Najwyższy postawił tezę, że „jeżeli przez stronę powodową została dowiedziona podstawa faktyczna, wcześniej wskazana w pozwie, zgodnie z art. $187 \$ 1$ pkt

${ }^{43}$ Zob. K. Weitz, Związanie..., s. 696-697 oraz powołana tam literatura, a także K. Markiewicz, w: Kodeks postępowania cywilnego. Tom I. Art. 1-366, pod red. A. Marciniaka, K.. Piaseckiego, Warszawa 2016, s. 1393-1394 oraz powołane tam orzecznictwo. Za dopuszczalnością rozważenia wszystkich podstaw prawnych i brakiem związania sądu wskazaniami prawnymi strony opowiedział się m.in. K. Piasecki, Zasady..., w: System..., s. 272; A. Struzik, Da mihi, w: Aurea..., s. 600; J. Misztal-Konecka, Zakaz wyrokowania..., s. 52-53.

${ }^{44}$ II CR 305/57, OSNC 1958, nr 3, poz. 72.

${ }^{45}$ I CKN 252/98, OSNC 1999, nr 9, poz. 152.

${ }^{46}$ I CKN 902/99, niepubl.

${ }^{47}$ IV CSK 269/06, niepubl.

${ }^{48}$ II CSK 524/07, niepubl.

${ }^{49}$ III CSK 17/08, niepubl. 
2 k.p.c. i z zachowaniem wymagań dowodowych, jakie wynikają dla sprawy gospodarczej z art. 479[12] k.p.c., pozwalająca na rozstrzygnięcie sporu między stronami w sposób przewidziany prawem, to art. 321 k.p.c. nie stoi na przeszkodzie, zastosowaniu przez sąd rozpatrujący sprawę innej podstawy prawnej, niż ta podana przez powoda przy wszczęciu postępowania, chyba że zgłaszający roszczenie żądałby rozstrzygnięcia wyłącznie na gruncie tej, wskazanej przez siebie podstawie prawnej"50.

W ocenie autorki pracy, biorąc pod uwagę fakt, że sąd nie jest związany podstawą prawną powołaną przez powoda i że to sąd stosuje prawo, obowiązkiem sądu przy tak skonstruowanym stanie faktycznym jest rozważenie zastosowania wszystkich podstaw prawnych, według których stan ten może być kwalifikowany. Powód wskazując podstawę prawną dochodzonego roszczenia, nie może ograniczać sądu w stosowaniu prawa, zwłaszcza w takich sprawach, w których do powołanego przez powoda stanu faktycznego można zastosować różne przepisy. Ograniczenie się powoda do wskazania jednej podstawy prawnej może wynikać z niewiedzy powoda, ale może być też przemyślaną decyzją związaną z przyjętą przez niego strategią procesową, tym niemniej ani w jednym ani w drugim wypadku, z uwagi na brak podstawy prawnej, nie może rzutować na zakres orzekania sądu. Należy jednak dodać, że postawiona teza dotyczy tylko takich stanów faktycznych, które można kwalifikować według różnych podstaw prawnych, bez zmiany lub uzupełniania przez sąd z urzędu okoliczności powołanych przez strony. Poszukiwanie przez sąd prawidłowej podstawy prawnej rozstrzygnięcia możliwe jest bowiem tylko w odniesieniu do żądania powoda oraz powołanych przez strony w toku postępowania okoliczności faktycznych i nie może ono wykraczać poza te elementy. Sąd dla zastosowania wybranej przez siebie i „pasującej” normy prawnej nie może uzupełniać lub zmieniać stanu faktycznego. Natomiast jeżeli powód konstruuje stan faktyczny sprawy "dopasowując" go do powołanej przez siebie podstawy prawnej, powinien liczyć się z tym, że w wypadku gdy jego pogląd na sprawę okaże się nietrafny (np. wskutek odmiennej oceny przez sąd stanu faktycznego lub uznania pewnych faktów za nieudowodnione), to może z tego powodu przegrać sprawę.

W najnowszym orzecznictwie Sądu Najwyższego zaprezentowane zostało także stanowisko, że do istoty konstytucyjnego prawa do sądu należy sprawiedliwość proceduralna; obejmuje ona prawo do rzetelnego procesu, w którym podstawowym uprawnieniem jest możność bycia wysłuchanym. Naruszenie przez sąd tego uprawnienia stron przez rozstrzygnięcie o roszczeniu na innej podstawie prawnej niż wskazywana przez stronę, bez poinformowania o takiej możliwości przed zamknięciem rozprawy, skutkuje nieważnością postępowania

50 II CSK 189/09, nieubl. 
z powodu pozbawienia strony możności obrony jej praw ${ }^{51}$. Trudno się do końca zgodzić ze zdaniem drugim postawionej wyżej tezy, zwłaszcza w odniesieniu do procesów, w których strony reprezentowane są przez profesjonalnych pełnomocników procesowych lub gdy przedstawiony przez stronę stan faktyczny można zakwalifikować na podstawie różnych przepisów prawa.

W literaturze oraz orzecznictwie analizuje się również kwestię, jak ocenić powołanie przez powoda podstawy prawnej żądania z punktu widzenia określenia jego podstawy faktycznej. Wskazuje się, że powołanie podstawy prawnej ma takie znaczenie, że jest ona nośnikiem konkretnych treści faktycznych ${ }^{52}$. Sąd Najwyższy w wyroku z dnia 28 lutego $2002 \mathrm{r}^{53}$ postawił tezę, że zgodnie z art. 187 $\$ 1$ pkt 2 k.p.c. powód ma obowiązek wskazania tylko okoliczności faktycznych uzasadniających żądanie pozwu i nie musi przytaczać jego podstawy prawnej, podanie jednak tej podstawy przez profesjonalnego pełnomocnika niewątpliwie ukierunkowuje całe postępowanie w sprawie. To ukierunkowanie nie może jednak oznaczać formalnego związania sądu wskazaną podstawą żądania ${ }^{54}$. Zdaniem K. Weitza zbyt daleko idące jest natomiast zapatrywanie, że tą drogą wytyczona zostaje granica okoliczności faktycznych, które są między stronami sporne albo niesporne i które mogą stanowić podstawę faktyczną żądania. Nie ma także uzasadnienia uogólnienie, że powołanie określonej podstawy prawnej oznacza, iż powód poddaje pod osąd tylko te fakty, które mogą służyć zastosowaniu wskazanych przez niego przepisów. Stanowisko to byłoby trafne tylko wtedy, gdyby powód poza wskazaniem danej podstawy prawnej żądania nie powołał okoliczności faktycznych wykraczających poza fakty, które powołał w sposób pośredni, podając podstawę prawną żądania, i które wystarczają do tego, aby zastosować dane przepisy ${ }^{55}$.

Z kolei jeżeli chodzi o ostatnie z wybranych spornych zagadnień wyłaniających się na tle art. $321 \$ 1$ k.p.c., to należy zauważyć, że według jednego poglądu nie jest uważane za naruszenie zakazu $\mathrm{z}$ art. $321 \$ 1$ k.p.c. precyzowanie przez sędziego przedmiotu sporu ${ }^{56}$. Natomiast według innych poglądów należy w tym zakresie odróżnić różne wypadki, tj. czy mamy do czynienia z brakami formalnym pozwu przy formułowaniu żądania, czy też zawarte w pozwie żądanie nie zostało ujęte w poprawnej pod względem jurydycznym formie, czy też zachodzi sprzeczność między tym żądaniem a okolicznościami faktycznymi przytoczo-

${ }^{51}$ SN w wyroku z dnia 2 grudnia 2011 r., III CSK 136/11, niepubl. z glosą częściowo krytyczną E. Łętowskiej, PPC 2012, nr 4, s. 684 i n. Tak też SN w wyroku z dnia 19 marca 2015 r., IV CSK 368/14, niepubl.

${ }^{52}$ K. Weitz, Związanie..., s. 697.

53 III CKN 182/01, niepubl.

54 Tezę tą raz jej uzasadnienie podzielił A. Struzik, Da mihi, w: Aurea..., s. 608-609.

55 K. Weitz, Związanie..., s. 697.

${ }^{56}$ K. Piasecki, Zasady, w: System..., s. 272. 
nymi przez powoda na jego uzasadnienie. Jeżeli żądanie sformułowane przez powoda jest nieprecyzyjne, tj. w szczególności trudno na jego podstawie określić przedmiot sporu lub ustalić, czego powód się domaga, przewodniczący w trybie art. 130 k.p.c. powinien wezwać powoda do uzupełnienia lub poprawienia pisma. Nieprecyzyjność żądania może również przejawiać się w tym, że nie jest ono sformułowane poprawnie jurydycznie. W takim wypadku, sąd może dokonać jego wykładni i biorąc pod uwagę wolę powoda, nadać temu żądaniu jurydyczną formę. Sąd, dokonując wykładni żądania, powinien wziąć pod uwagę nie tylko jego treść, ale także uzasadnienie faktyczne ${ }^{57}$. Sąd z jednej strony powinien zatem rozstrzygnąć sprawę $\mathrm{w}$ granicach zakreślonych mu przez powoda, $\mathrm{z}$ drugiej zaś nadać swojemu rozstrzygnięciu poprawną pod względem prawnym formę. Związanie żądaniem pozwu nie oznacza bowiem, że sąd powinien, o ile uznaje żądanie powoda za uzasadnione $\mathrm{w}$ świetle przytoczonych przez niego okoliczności, lecz niepoprawnie pod względem jurydycznym sformułowane, je powtórzyć w wyroku i nie może wprowadzić do niego żadnych zmian. Mówiąc o zmianach, autorka pracy ma jednak na myśli nie zmiany ilościowe lub jakościowe żądania, lecz zmiany polegające na tym, że wola powoda wyrażona $\mathrm{w}$ żądaniu zostanie zachowana, lecz ujęta w poprawnej prawnie formie. Od żądania nieprecyzyjnego należy odróżnić żądanie sprzeczne z okolicznościami faktycznymi powołanymi na jego uzasadnienie. W takim wypadku możliwe są w zasadzie trzy rozwiązania: sąd orzeka zgodnie z zasadą z art. $321 \S 1$ k.p.c. i oddala powództwo jako bezzasadne albo sąd pomija żądanie powoda i tym samym treść art. $321 \$ 1$ k.p.c. i orzeka o żądaniu wynikającym z przytoczonych przez niego okoliczności, albo sąd podejmuje próbę skonwalidowania tego żądania, pouczając stronę o możliwości ustanowienia pełnomocnika procesowego (art. 5 i 212 k.p.c.) ${ }^{58}$. W obecnym stanie prawnym trafne wydaje się być tylko pierwsze ze wskazanych rozwiązań, sąd nie może bowiem zastępować strony powodowej w formułowaniu jej żądań. Odmienne stanowisko z jednej strony prowadziłoby do podważenia obowiązującej w procesie cywilnym zasady dyspozycyjności, z drugiej zaś strony stawiało pod znakiem zapytania realizację drugiej obowiązującej w tym procesie zasady - zasady równości.

\section{Wnioski}

Zasada ne eat iudex ultra petita partium niewątpliwie wywodzi się z tradycji rzymskich i tam też należy poszukiwać jej korzeni. Pomimo zmian regulacji prawnych dotyczących tej zasady obecnie obowiązuje ona w polskim procesie

\footnotetext{
57 Zob. tė̇ K. Weitz, Związanie..., s. 708-709.

58 Bliżej K. Weitz, Związanie..., s. 710-711; K. Markiewicz, w: Kodeks..., s. 1392-1393.
} 
cywilnym zasadniczo w swoim klasycznym kształcie, umożliwiając tym samym stronie realizację jej prawa do uzyskania ochrony prawnej zgodnie z jej wolą wyrażoną przed sądem. Zasada ta jest zatem istotnym instrumentem umożliwiającym stronom dysonowanie ich prawami. Pomijając wyjątki wynikające z ustawy, w których sąd może orzekać bez żądania strony lub zmienić to żądanie, zasada ta służy do zakreślenia przez stronę sądowi granic badania sprawy i orzekania o niej. Zasada ta doczekała się licznych opracowań naukowych oraz wypowiedzi Sądu Najwyższego. Jej stosowanie w praktyce wywołuje bowiem wiele wątpliwości. Wątpliwości te dotyczą m.in. takich kwestii jak dopuszczalność zmiany przez sąd okoliczności faktycznych uzasadniających żądanie, znaczenie dla rozstrzygnięcia sprawy podstawy prawnej powołanej przez stronę czy też związanie sądu „treścią lub formą” żądania. Odnosząc się do tych wątpliwości, warto na koniec przypomnieć najistotniejsze z poczynionych wyżej ustaleń. Otóż zasada ne eat iudex ultra petita partium uniemożliwia sądowi co do zasady zmianę żądania powoda lub okoliczności faktycznych powołanych na jego uzasadnienie. Zmiany, jakie może wprowadzić sąd do żądania powoda, mogą polegać zasadniczo jedynie na tym, że sąd ujmie żądanie w poprawnej pod względem prawnym formie, zachowując przy tym wolę powoda. Sąd nie jest natomiast związany podstawą prawną powołaną przez powoda i powinien zastosować właściwą w jego ocenie normę prawną, niezależnie od tego, czy strona powołała się na nią. To sąd rozpoznający sprawę stosuje bowiem prawo w granicach zakreślonych mu przez powoda zgodnie z treścią art. $321 \S 1$ k.p.c.

\section{Wykaz literatury}

Amielańczyk K., Zasada skargowości i zakaz orzekania ponad żądanie stron w procesie rzymskim, Gdańskie Studia Prawnicze 2015, z. 33.

Berutowicz W., Postępowanie cywilne w zarysie, Warszawa 1978.

Broniewicz W., recenzja pracy K. Piaseckiego, Wyrok pierwszej instancji w procesie cywilnym, Warszawa 1981, Pal. 1982, nr 6-7.

Ereciński T., Orzekanie ponad żądanie w sprawach o naprawienie szkody wyrządzonej czynem niedozwolonym (kilka uwag na tle art. 321 § 2 k.p.c.), w: Odpowiedzialność cywilna. Księga pamiątkowa ku czci Profesora Adama Szpunara, Kraków 2004.

Ereciński T., Weitz K., Efektywność ochrony prawnej udzielanej przez sądy w Polsce, PS 2005, nr 10. Ignatowicz J., Ochrona posiadania, Warszawa 1963.

Jodłowski J., Z zagadnień polskiego procesu cywilnego, Warszawa 1961,

Korzan K. Orzeczenia konstytutywne w postępowaniu cywilnym, Warszawa 1972.

Mańkowski W., Projekt działu polskiej procedury cywilnej o wyrzeczeniach sq̨dowych, w: Polska procedura cywilna. Projekty referatów z uzasadnieniem. Przedruk wyczerpanych druków z r. 1921 i 1923. Tom I, Warszawa 1928.

Krajewski J., Odrębności postępowania posesoryjnego, NP 1961, nr 2.

Kunicki A., Wyrokowanie w sprawach posesoryjnych, NP 1962, nr 12.

Kupiszewski H., Znaczenie prawa rzymskiego dla współczesności, PiP 1981, z. 8. 
Kupiszewski H. Prawo rzymskie a współczesność, Warszawa 1988.

Kuryłowicz M., Rzymskie sentencje prawnicze o człowieku, sprawiedliwości i prawie, Palestra 1988, nr 7.

Łętowska E., glosa do wyroku SN z 18 marca 2005 r., Il CK 556/04, PiP 2005, z. 10.

Łętowska E., glosa do wyroku SN z dnia 2 grudnia 2011 r., III CSK 136/11, PPC 2012, nr 4.

Manowska M., Postępowania odrębne w procesie cywilnym, Warszawa 2010.

Markiewicz K., w: Kodeks postępowania cywilnego. Tom I. Art. 1-366, pod red. A. Marciniaka, K. Piaseckiego, Warszawa 2016.

Misztal-Konecka J., Zakaz wyrokowania ponad żądnie strony(„,Ne eat iudex ultra petita partium") - Rzymski tradycje i współczesne regulacje polskiego procesowego prawa cywilnego, Zeszyty Prawnicze 12.4/2012.

Osowy P., Roszczenie posesoryjne na przykładzie powództwa o wstrzymanie budowy - spójność uregulowań k.c.i k.p.c. (zagadnienia proceduralne), Rejent 2002, nr 4.

Osowy P., Pełczyński P., Sądowa ochrona posiadania - zagadnienia spójności uregulowań kodeksu cywilnego $i$ kodeksu postępowania cywilnego, PS 2001, nr 6.

Piasecki K., Orzekanie ponad żądanie w procesie cywilnym, Warszawa 1975.

Piasecki K., Wyrok pierwszej instancji w procesie cywilnym, Warszawa 1981.

Piasecki K., Zasady orzekania, w: System prawa procesowego cywilnego. Postępowanie rozpoznawcze przed sadami pierwszej instancji. Tom II, pod red. Z. Resicha, red. naczelny W. Berutowicz, Wrocław-Warszawa-Kraków-Gdańsk-Łódź 1987.

Pogonowski P., Znaczenie rzymskich paremii procesowych dla współczesnej procedury cywilnej, [w:] Starożytne kodyfikacje prawa, pod red. A. Dębińskiego, Lublin 2000,

Pogonowski P., Realizacja prawa do sq̨du w postępowaniu cywilnym, Warszawa 2005.

Ruta D., Merytoryczna obrona pozwanego w postępowaniu w sprawach o naruszenie posiadania, Pal. 2012, nr 5-6.

Siedlecki W., Zasady wyrokowania w procesie cywilnym, Warszawa 1957.

Siedlecki W., Zasady orzekania w postępowaniu cywilnym, NP 1965, nr 6.

Stelmachowski A., Istota i funkcja posiadania, Warszawa 1958.

Struzik A., Da mihi factum dabo tibi ius, w: Aurea Praxis Aurea Theoria. Księga pamiątkowa ku czci profesora Tadeusza Erecińskiego, pod red. J. Gudowskiego, K. Weitza, tom I, Warszawa 2011.

Telenga P., w: Kodeks postępowania cywilnego. Tom I. Art. 1-729, pod red. A. Jakubeckiego, Warszawa 2017.

Weitz K., Zwiq̨zanie sq̨du granicami żądania w procesie cywilnym, w: Aurea Praxis Aurea Theoria. Księga pamiątkowa ku czci profesora Tadeusza Erecińskiego, pod red. J. Gudowskiego, K. Weitza, tom I, Warszawa 2011.

Wołodkiewicz W., Tradycja prawa rzymskiego we współczesnym prawie cywilnym, Palestra 1987, nr 10-11.

Wołodkiewicz W., Czy prawo rzymskie przestało istnieć?, Palestra 1999, nr 9-10.

Wołodkiewicz W., Europa i prawo rzymskie. Szkice z historii europejskiej kultury prawnej, Warszawa 2009.

Wołodkiewicz W. w: Regulae iuris. Łacińskie inskrypcje na kolumnach Sądu Najwyższego Rzeczypospolitej Polskiej, pod red. W. Wołodkiewicza, Warszawa 2011.

Wołodkiewicz W., Zabłocka M., Prawo rzymskie. Instytucje, Warszawa 1995.

\section{Wykaz orzeczeń}

Wyrok SN z dnia 2 maja 1957 r., Il CR 305/57, OSNC 1958, nr 3, poz. 72.

Wyrok SN z dnia 23 lutego 1999 r., I CKN 252/98, OSNC 1999, nr 9, poz. 152.

Wyrok SN z dnia 13 marca 2002 r., III CKN 568/99, niepubl. 
Wyrok SN z dnia 28 lutego 2002, III CKN 182/01, niepubl. Wyrok SN z dnia 12 lutego 2002 r. I CKN 902/99, niepubl. Wyrok SN z dnia 6 grudnia 2006 r., IV CSK 269/06, niepubl. Wyrok SN z dnia 27 marca 2008 r., II CSK 524/07, niepubl. Wyrok SN z dnia 9 maja 2008 r., III CSK 17/08, niepubl. Wyrok SN z dnia 16 września 2009 r., II CSK 189/09, nieubl. Wyrok SN z dnia 14 stycznia 2009 r., IV CSK 385/08, niepubl. Wyrok SN z dnia 2 grudnia 2011 r., III CSK 136/11, niepubl. Wyrok SN z dnia 19 marca 2015 r., IV CSK 368/14, niepubl.

\section{Wykaz aktów prawnych}

Kodeks postępowania cywilnego, który został ogłoszony rozporządzeniem Prezydenta RP z dnia 29 listopada 1930 r., z mocą obowiązującą od 1 stycznia 1933 r. (Dz. U. RP z 1930 r. Nr 83, poz. 651). Osobno opracowano tekst prawa egzekucyjnego, który został ogłoszony rozporządzeniem Prezydenta RP z dnia 27 października 1932 r. jako prawo o sądowym postępowaniu egzekucyjnym. Obwieszczeniem Ministra Sprawiedliwości z dnia 1 grudnia 1932 r. ogłoszono jednolity tekst k.p.c., łączący obie części kodeksu (Dz. U. z 1932 r. Nr 112, poz. 934 ze zm.), który wprowadzał też nową numerację przepisów.

Obwieszczenie Ministra Sprawiedliwości z dnia 25 sierpnia 1950 r. o ogłoszeniu tekstu jednolitego kodeksu postępowania cywilnego z 1930 r. (Dz. U. z dnia 30 listopada 1950 r. Nr 43, poz. 394; sprost.: Dz. U. z 1950 r. Nr 53, poz. 489 ze zm.).

Ustawa z dnia 20 lipca 1950 r. o zmianie przepisów postępowania w sprawach cywilnych, Dz. U. z 1950 r. Nr 38, poz. 349.

Ustawa z dnia 13 lipca 1990 r. o zmianie ustawy - Kodeks postępowania cywilnego, Dz. U. 1990 r. Nr 55, poz. 318.

Ustawa z dnia 2 lipca 2004 r. o zmianie ustawy - Kodeks postępowania cywilnego oraz niektórych innych ustaw, Dz. U. 2004 r. Nr 172, poz. 1804.

Ustawa z dnia 18 kwietnia 1985 r. o zmianie ustawy - Kodeks postępowania cywilnego, Dz. U. 1985 r. Nr 20, poz. 86.

Ustawa z dnia 2 lutego 1996 r. o zmianie ustawy - Kodeks pracy oraz o zmianie niektórych ustaw, Dz. U. 1996 r. Nr 24, poz. 110.

Ustawa z dnia 2 lipca 2004 r. o zmianie ustawy - Kodeks postępowania cywilnego oraz niektórych innych ustaw, Dz. U. 2004 r. Nr 172, poz. 1804.

Ustawa z dnia 17 listopada 1964 r. Kodeks postępowania cywilnego, tekst jednolity z 2016 r., poz. 1822 ze zm.

Ustawa z dnia 21 czerwca 2001 r. o ochronie praw lokatorów, mieszkaniowym zasobie gminy i o zmianie Kodeksu cywilnego, tekst jednolity: Dz. U. z 2016 r., poz. 1610 ze zm.

\section{Streszczenie}

Zasada ne eat iudex ultra petita partium, czyli niech nie wychodzi sędzia ponad żądania stron ujmowana jest współcześnie jako zakaz orzekania przez sąd ponad żądanie. Zasada ta nie znajduje dosłownego potwierdzenia w tekstach prawa rzymskiego. Pochodzi ona z późniejszych opracowań nawiązujących do tego prawa. W prawie współczesnym sentencja ta jest wyrazem jednej z podstawowych i zarazem najważniejszych zasad orzekania oraz gwarancją realizacji w procesie cywilnym zasady dyspozycyjności. Zasada ta bowiem wskazuje na to, że uprawnienie do wszczęcia procesu cywilnego 
oraz do wyznaczenia granic poszukiwanej ochrony prawnej przysługuje uprawnionemu podmiotowi. Co z kolei wyraża się w tym, że sąd nie może wszcząć procesu bez wniosku (pozwu) strony, nie może orzekać co do przedmiotu, który nie był objęty żądaniem ani zasądzać ponad żądanie. W celu omówienia tytułowego zagadnienia w artykule przybliżono w pierwszej kolejności genezę tej zasady, następnie ewolucję historycznoprawna polskiej regulacji prawnej odnoszącej się do tej zasady, aby w końcu krótko przedstawić kształt, jaki tej zasadzie nadał ustawodawca polski w kodeksie postępowania cywilnego.

Słowa kluczowe: postępowanie rozpoznawcze, żądanie, okoliczności faktyczne, zakres orzekania, zasady orzekania

\section{Ne eat iudex ultra petita partium from Roman law to modern times. Remarks on the background of the Polish civil process}

\section{Summary}

The principle ne eat iudex ultra petita partium, that is let the judge does not go beyond the demands of the parties is nowadays recognized as a prohibition of judicial over the demand. This principle is not literally confirmed in the texts of Roman law. It comes from later studies referring to this law. In modern law, this sentence is an expression of one of the basic and at the same time the most important rules of adjudication and the guarantee of the implementation of the principle of availability in the civil process. The rule is the right to initiate a civil trial and to determine the limits of the legal protection sought are vested in the legitimate entity. In turn, it is expressed in the fact that the court is not allowed to initiate the trial without the party's claim it is not allowed to decide on the object that was not covered by the request or award more than the request. In order to discuss the title issue in the paper, the genesis of that principle and then the historical and legal evolution of the Polish legal regulations related to this principle was briefly presented in the paper, in order to present briefly the form which the Polish legislature gave in the Code of Civil Procedure.

Keywords: reconnaissance, request, factual circumstances, scope of adjudication, rules of adjudication. 